\title{
СРАВНИТЕЛЬНЫЙ АНАЛИЗ АКТУАЛИЗАЦИИ ГЛАГОЛЬНЫХ ЗНАЧЕНИЙ В ПЕРЕВОДАХ РУССКИХ И ВЕНГЕРСКИХ НОВОСТНЫХ ГАЗЕТНЫХ СТАТЕЙ
}

Настоящая работа ставит перед собой цель проанализировать общественно-информативные тексты, точнее выполнить сравнение актуализации глагольных значений в новостных газетных статьях (параллельные тексты) венгерского и русского языков. Автор выявляет контекстуально обусловленные значения некоторых глаголов, (употребляемых в параллельных текстах), функционирование и актуализацию значений многозначного глагола. Эмпирическим материалом исследования послужили венгерские и русские газеты, журналы, новостные интернет-порталы. В анализе новости русских и также венгерских источников переведены автором и представляют собой эквивалентные и адекватные тексты - передающие новости одинакового содержания.
Актуальность работы состоит в том, что путем сопоставительного анализа выявлены различия между переводческими решениями (каждый перевод субъективен в этом смысле), как преодолеваются типовые трудности перевода связанные со спецификой венгерского и русского языков, также выявляются расхождения на фоне контекстуального значения. Эти факторы во многом влияют и на восприятие и интерпретацию одной и той же новости, переданной на разных языках и обнаруживаются конкретные расхождения в фокусах продуцента и реципиента.

Ключевые слова: публицистический стиль, новости в газетных статьях, сопоставительный анализ, грамматика русского и венгерского языков, трудности перевода.

\section{A. Tuboly}

\section{COMPARATIVE ANALYSIS OF THE ACTUALIZATION OF VERBAL VALUES IN TRANSLATION OF THE RUSSIAN AND HUNGARIAN NEWSPAPERS}

The article describes what kind of linguistic differences appear during the analysis of Hungarian and Russian newspaper articles, performs a comparative analysis of actualization of the verbal meanings in news articles (parallel texts).

This work aims to identify the contextually determined meanings and functioning of russian and hungarian verbs, also presents the differences between the grammar systems of the two mentioned languages.

The empiric basis of the work are Hungarian and Russian newspapers, magazines and various Internet portals transmitting the news of the world. In the analysis of the news of Russian and also Hungarian sources translated by author and are considered as equivalent and adequate Newspaper texts - representing news of the same content in both languages.

\section{1. Публицистический стиль и его языко- вые нормы}

Как известно, перевод - это одно из древнейших занятий человека. Различие языков побудило людей к этому занятию, которое служит целям общения и обмена духовными цен-
The relevance of this work is that using a comparative analysis as a method, it is possible to identify the differences between translation solutions and strategies (each translation is subjective in this aspect), how the typical translation difficulties associated with the specific meanings of the Hungarian and Russian languages. These factors in many ways affect the perception and interpretation of the same news, transmitted in different languages, and there are specific differences between the focuses of producer and receptor as well.

Key words: journalistic style, news reporting, comparative analysis, Russian and Hungarian grammar systems, translation difficulties.

ностями между народами. Слово «перевод» многозначно, и у него есть два терминологических значения, первое из них определяет мыслительную деятельность, процесс передачи содержания, выраженного на одном языке средствами другого языка. Второе - называет 
результат этого процесса - текст устный или письменный. Перевод - это деятельность по интерпретации смысла текста на исходном языке, и созданию нового, эквивалентного текста на языке перевода. Целью перевода является установление отношений эквивалентности между исходным и переводным текстом, для того, чтобы оба текста несли в себе одинаковой смысл.

Задачей перевода являются поиски соотносительных и параллельных способов выражения содержания подлинника - из состава средств другого языка. Переводчик всегда имеет дело с различными стилями общенационального языка, он всегда учитывает их соотношение и взаимопроникновение, равно как и формы отношения средств выражения к передаваемому содержанию [21, р. 29].

Тексты для переводов разнообразны по жанрам, стилям и функциям. Поэтому переводчику важно знать, какой вид текста ему надлежит переводить. Типы текстов определяют требования к переводу, из этого следует, что цели и задачи переводчика оказываются различными в зависимости от того, что он переводит, ведь у каждого из жанров имеют свои особенности.

Принимая во внимание функции языка и стили речи, целесообразно выделить шесть основных функционально-стилевых типов текСтов:

1. Разговорные тексты: Они выполняют функцию общения, реализуются в устной диалогической форме.

2. Офрициально-деловые тексты: К этой группе относятся государственные, политические, дипломатические, юридические и тому подобные тексты.

3. Общественно-информативные тексты: Содержат самую различную информацию, подходящую по каналам массовой коммуникации, газетам, журналам, радио и телевидению. Их главная функция - информирование.

4. Научные тексты: Среди них выделяются, прежде всего, тексты специальные, научно-популярные. Они реализуются главным образом в письменной форме.

5. Художественные тексты: В этих текстах используются единицы и средства всех стилей, но все эти стилевые элементы включаются в особую литературную систему и приобретают новую эстетическую функцию.

6. Религиозные сочинения: Их содержание отличается своеобразием. Основное место среди них занимают канонические книги Священного писания, апокрифы, теологические тексты [5, p. 16-17].
В процессе перевода проблема передачи стилистических приемов состоит в том, что эти своеобразия вызывают затруднения у переводчика из-за национальных особенностей стилистических систем разных языков. Воссоздание адекватного прагматического эффректа оригинала в переводе также ставит трудности перед переводчиком. Параметры адекватности этих образных средств разделяются на следующие: передача семантической информации, передача эмоционально-оценочной информации, передача экспрессивной и эстетической информации. Если семантическая основа подлинника передана точно, результатом перевода является адекватное смысловое содержание.

Слово публицистический происходит от слова publicare, publicus и имеет значение 'сделать общим, открыть для всех, объяснить, обнародовать'. Публицистика - особый тип литературных произведений, в которых разъясняются актуальные вопросы общественно-политической жизни, поднимаются нравственные проблемы.

Этот стиль широко употребляется в периодической печати, то есть в газетах, журналах, также в радио- и телепередачах, в публичных выступлениях и тому подобное. Цель публицистического текста - оказать желаемое воздействие на разум и чувства читателя, слушателя, он сочетает фрункции сообщения и воздействия, чтобы повлиять на мысли читателей, реализуя побудительную функцию.

Среди языковых особенностей стиля необходимо назвать использование специальной терминологии, эмоционально окрашенной лексики, использование и абстрактной, и конкретной лексики. Сам стиль является наиболее продуктивным каналом в рождении языковых неологизмов, исходя из этого, можно сказать, что оказывает и значительное влияние на развитие языковой нормы. Особенностью публицистического стиля является употребление широкого спектра средств литературного языка: от научных и специальных терминов до слов обыденной разговорной речи. Жанрами публицистики являются репортаж, интервью, статья, зарисовка, очерк, фрельетон.

Среди лексических черт следует отметить употребление специальной лексики, для данного стиля характерна широкая полисемия, при которой лексема зачастую употребляется в переносном значении, наблюдается явление многозначности и метафоризации.

Среди стилистических средств языка средств массовой информации Ю. В. Рождественский выделяет две группы отграничивает 
признаваемое и отвергаемое. В семантическую сфреру признаваемого входят все предметы (лица, документы, события), которые считаются позитивными с точки зрения органа информации, а в семантическую сферу отвергаемого входят такие предметы, которые считаются негативными [18, р. 249].

Цель публицистического текста сообщить новые сведения, и не столько донести информацию, сколько представить суждения об этой информации. Кроме этого, у этих текстов есть еще одна цель - воздействовать на читателя. Передача информации находит свое выражение в денотативной функции, передавая информацию о денотате, а воздействующая функция связано с экспрессивной функцией. Передача информации редко бывает полностью нейтральной.

Текстами этого жанра часто являются частью какой-то газеты, однако авторская личность не всегда проявляется в тексте, реципиентами являются широкие массы населения. С этой точки зрения, передача информации происходит как бы „безлично”, в виду и того, что сам переводчик и внесет субъективные оттенки в этом процессе.

Публицистический стиль характеризуется и высокой степенью клишированности. Клише в этих текстах употребляется как определенный сигнал, создает повышенный эмоциональный фон, но при этом не мешает восприятию когнитивной информации. Можно сказать, что через клише передается оценка автора.

1.1. Особенности перевода газетно-информационных статей

Материалы газетно-информационного жанра составляют основное содержание газетных текстов. В наши дни средства массовой информации оказывают огромное влияние на жизнь людей, также на национальные языки и культуры. Исходя из этого, проблема перевода средств массовой информации становиться актуальной.

Газета - это средство информации и убеждения. Как уже было сказано выше, основная ее задача заключается в сообщении определенных сведений с определенных позиций с целью достижения желаемого воздействия на читателя. Характерная особенность газетного-информационного материала заключается и в стилистической разноплановости лексики, которая отличает газетные тексты от научно-технической информации и от художественной и научной прозы. Французский лингвист Ш. Балли и писал, что научный язык - это язык идей, а художественная речь - язык чувств.
К этому можно добавить, что публицистика язык и мыслей и чувств [2, р. 281].

Лексико-грамматическая специфика стиля проявляется в газетных заголовках. Венгерские газеты, как правило, используют в заголовках не перфектные формы глагола, в русских прессах в большинстве случаев также употребляются эти формы глагола. В заголовках особенно широко используются и фразеологизмы и устойчивые выражения. Если в самой статье какая-либо ситуация описывается в более сдержанном стиле, заголовка часто носит разговорный характер (нп: Поживем увидим - Ha megérjük, meglátjuk). Синาтаксис газетных материалов характеризуется частым употреблением сложных, особенно сложноподчинен ᄀных предложений, причастных и деепричастных оборотов, также использованием пассивных конструкций.

Когда речь идет о событиях, происшедших в недавнем прошлом, обычно употребляется форма прошедшего времени в обоих языках. (нп: Медведев вылетел на похороны Качиньского - Medvegyev orosz elnök Kaczynski temetésére repült).

Перевод газетно-информационной литературы представляет собой отдельный интерес для изучения по своей актуальности и насущности. Жанр газетно-информационной литературы представляет собой материалы печатно-периодических изданий, в которых публикуются новости о самых разнообразных событиях текущей жизни, или источники, несущие в себе ту или иную информацию. При переводе такого жанра литературы существуют различные особенности и сложности. Эмоционально окрашенные слова или определенные выражения могут неодинаково восприниматься разными людьми, тем более, если эти люди представляют собой разные языковые и этнические коллективы. Исходный текст будет переводиться по-разному в зависимости от того, для кого предназначен перевод, и может оказаться необходимым вносить в перевод какие-то изменения, чтобы адаптировать его к требованиям рецептора и его культуры.

2. Сопоставительный анализ актуализации глагольных значений в переводах новостных газетных статей русского и венгерского языков

2.1. Переводческая эквивалентность и контекстуальное значение

Задача любого перевода - передать средствами другого языка целостно и точно содержание подлинника, сохранив его стилистические и экспрессивные особенности. Перевод 
должен нести в себе не только то, что выражено подлинником, но и то, как это выражено. Для определения степени общности содержания (смысловой близости) оригинала и перевода были введены понятия эквивалентности и адекватности. В теории и практике перевода оперируют такими сходными понятиями, как эквивалентность, адекватность и тождественность.

В широком плане эквивалентность понимается как нечто равноценное, равнозначное чему-либо, адекватность - как нечто вполне равное, а тождество - как нечто обладающее полным совпадением, сходством с чем-либо.

Следует различать достижимую эквивалентность, под которой понимается максимальная общность содержания двух текстов, и переводческую эквивалентность, то есть реальную смысловую близость текстов оригинала и перевода. Пределом переводческой эквивалентности является максимально возможная степень сохранения содержания оригинала при переводе, однако в каждом отдельном переводе смысловая близость к оригиналу в разной степени и разными способами приближается к максимальной (различия в системах исходящего и переводящего языков). Цель перевода состоит в сохранении содержания, функций, стилевых, стилистических, коммуникативных ценностей оригинала.

Задачей переводоведения является изучение всех контекстных связей при переводе (как процесс), а также контекстной семантики. Под лингвистическим контекстом понимается языковое окружение, в котором употребляется та или иная лингвистическая единица. Так контекстом слова является совокупность слов, грамматических форм и конструкций, в окружении которых встречается данное слово [3, р. 169].

Н. Ю. Шведова в понятие контекст вкладывает содержание, соответствующее как тому, что называется указательным минимумом, так и тому, что служит языковым окружением, языковой обстановкой вообще [22, р. 31].

Как отмечает Л. С. Бархударов, в пределах общего понятия контекста различается узкий контекст (микроконтекст) и широкий контекст (макроконтекст). Узкий контекст можно разделить на контекст синтаксический и лексический. Синтаксический контекст - это та синтак- сическая конструкция, в которой употребляется данное слово, словосочетание или предложение. Лексический контекст - это совокупность конкретных лексических единиц, слов и устойчивых словосочетаний, в окружении которых встречается данная единица.

Наиболее наглядно и предельно убедительно роль контекста выступает при переводе текста с одного языка на другой. Любая многозначность языковых единиц поддается переводу не в силу некого абстрактного соответствия отдельных словарных единиц, а благодаря раскрытию всех контекстных связей элементарных единиц, образующий целый коммуникативный отрезок.

Многие слова приобретают в контексте такие значения, которые не входят в их смысловую структуру, эти значения возможны только в условиях данного контекста. Такие значения являются контекстуальными значениями. Контекстуальное значение является наиболее подвижной, неустойчивой, колеблющейся в своем содержании, оно не реализуется, а возникает в данном контексте. Считается, что основным значением многозначного слова является то, которое на данном отрезке времени чаще всего ассоциируется в сознании большинство носителей.

В связи с актуализацией потенциального контекстуального значения можно сказать, что контекстуальное значение возникает в процессе употребления слов в речи и в зависимости от окружения, и реализуются под действием узкого, широкого и экстралингвистического контекста. По степени частотности можно различать узуальные (повторяющиеся) и окказиональные (случайные, индивидуальные) контекстуальные значения.

2.2. Анализ актуализации глагольных значений в переводах газетных статей

При анализе эквивалентных ${ }^{1}$ газетных статей выявляются очень важные расхождения грамматического строя, различия и также общие черты глагольных конструкций двух языков. Возможные пути и фокусы анализа, здесь не имея в виду наш основный фокус работы, могут быть и нижеследующие, шаг за шагом, анализируя лексемы (см. таблицу).

Эквивалентными считаются переводы статей сделаны мною. (Статьи взяты из русско-и венгерскоязычных пресс считаются и равноценными с точки зрения передачи информации). 


\begin{tabular}{|l|l|l|l|}
\hline \multicolumn{1}{|c|}{ Русский оригинал } & \multicolumn{1}{|c|}{ Венгерский перевод } & \multicolumn{1}{|c|}{ Венгерский оригинал } & \multicolumn{1}{|c|}{ Русский перевод } \\
\hline Медведев вылетел на & Medvegyev orosz elnök & Az orosz elnök & Президент России при- \\
похороны Качиньского & Kaczynski temetésére & megérkezett Krakkóba & был в Краков \\
Президент России Дми- & repült & Rendben landolt Dmitrij & В воскресенье без всякой \\
трий Медведев вылетел & Dmitrij Medvegyev orosz & Medvegyev repülögépe & проблемы приземлился \\
из Москвы в Краков, чтобы & elnök Moszkvából Krakkóba & vasárnap a lengyelországi & самолет Медведева в \\
присутствовать на похоронах & repült, hogy részt vegyen & Krakkóban, ahol délután & польском Кракове, где \\
президента Польши Леха Ка- & a lengyel elnök - Lech & kettökor kezdödik a lengyel & и в два часа состоятся \\
чиньского. Об этом сообщает & Kaczynski - temetésén. & elnök és feleségének & похороны Леха и Мария \\
«Интерфракс» со ссылкой на & - számol be az Interfaksz & temetése. & Качинских. \\
пресс-секретаря президента & hírügynökség hivatkozva \\
Наталью Тимакову. & Natalja Timakovra, az elnök & & \\
& Szóvivőjére. & & \\
\hline
\end{tabular}

Заголовок русского оригинала «Медведев вылетел на похороны Качиньского» полностью соответствует переводу «Medvegyev orosz elnök Kaczynski temetésére repült», однако в венгерском оригинале Az orosz elnök megérkezett Krakkóba информация выражается имплицитно, так как в заголовке нет никаких указаний на цели путешествия, нет слов о похоронах. Для русского читателя сразу выясняется и вид транспорта как бы допольнительная информация при помощи глагола вылетел. В первом предложении русского оригинала глагол вылетел переводится словом repült. Употребление совершенного вида выражает единое, законченное действие, которое противопоставляется венгерскому глаголу несовершенного вида repült. Однако смысл заголовки включает в себе оттенки результативности, в контексте направление действия (Moszkvából Krakkóba) как бы подтвердит совершенность, результат действия.

Русский глагол вылетел образуется при помощи приставки - вы-, от корня - лет- со суффриксом -е- и глагольное окончание -ть. Венгерский глагол repült образуется от корня инфинитива repülni при помощи знака пошедшего времени -t-.

Семантическая теория перевода основывает переводческую эквивалентность на наличии общих сем в содержании оригинала и перевода.

Семантические описания ставят перед нами различные содержания глаголов, так как толкование глагола repül ('ember-repülőgépen utazik') и толкование глагола вылететь (1. 'Летя, направиться, отправиться куда-нибудь' Самолет вылетел по расписанию. Птенец вылетел из гнезда. Вылетело (безл.) из головы (перен.: забылось; разг.). 2. 'Летя, появиться откуда-н.' Самолет вылетел из-за облаков. 3. 'Оказаться уволенным, исключенным откуда-н.' (прост.) расходятся в значительной мере. Венгерский глагол не содержит никакого фразеологиче- ского оттенка, когда глагол вылететь носит в себе и коннотативное значение, причем образность. Используя толковые словари двух языков в ходе анализа, можно заметить и тот фракт, что русские словари передают значение слова более детально чем венгерские, также дают соответствующие в употреблении стилистические пласты.

Глагол присутствовать в русском оригинале переводится глаголом részt vesz формой которая образуется от инфинитива részt venni и употребляется в третьем лице единственного числа. Имея в виду семантические описания двух глаголов обнаруживаются одинаковые содержания и также общие черты в сфере употребления. Присутствовать: ' иметь место, иметься, наличествовать' передает тот же самый смысл как и венгерский глагол részt vesz 'elmegy valahová, hogy jelen legyen'.

В русском оригинале в предложении „Об этом сообщает «Интерфакс» со ссылкой на пресс-секретаря президента Наталью Тимакову" конструкция со ссылкой передается венгерским деепричастием hivatkozva. В русском обороте употребляется форма с+существительное в творительном падеже, а венгерский язык передает информацию деепричастием. „Dmitrij Medvegyev orosz elnök Moszkvából Krakkóba repült, hogy részt vegyen a lengyel elnök - Lech Kaczynski - temetésén. - számol be az Interfaksz hírügynökség hivatkozva Natalja Timakovra, az elnök szóvivőjére.”. В этом случае происходит замена частей речи. Интересно и обратить внимание на разное членение предложений в двух языках. В русском оригинале информация включена в двух предложении (см. выше, в таблице), а в подлиннике передается при помощи одного предложения. Здесь имеем дело с переводческой трансформацией, которая называется грамматической заменой, базирующиеся на разном членении предложения. 
Считается, что имена собственные переводятся как бы сами собой, автоматически. Значение имени собственного становится актуальным и при межкультурных и межъязыковых контактах. При переводе их на другой язык, они в основном сохраняют свой первоначальный звуковой облик. Слова «Интерфакс» и имена собственные Дмитрий Медведев и Наталя Тимаков переводятся при помощи транслитерации.

В ходе дальнейшего анализа - типа вышеуказанного - можно было бы выяснить подобные расхождения,возникающие в связи со структурой, и грамматическим своеобразием двух языковых систем. Но, на наш взгляд, важнее сам контекст и значение глаголов в нем, в дальнейшем анализируются несколько глаголов, при помощи которых можно обнаружить актуализацию разных значений в разных контекстах. Сам контекст придает той или иной единице языка однозначность и делает возможным выбор одного из нескольких потенциально существующих эквивалентов данной единицы в переводящем языке. Конечно, роль контекста далеко не ограничивается разрешением многозначности слов, однако важнейшая его функция заключается именно в этом.

В зависимости от характера контекстов различаются лексический, грамматический и сме- шанный (лексико-грамматический) типы контекста. При лексическом типе важно лексическое значение слов, под влиянием которых и происходит выбор семантически связанной с ними части значения ядра. Грамматический контекст возникает тогда, когда в роли индикатора выступает какая-либо грамматическая функция, но чаще всего, однако, для верного выбора части объема значения многозначного слова используется смешанный (лексико-грамматический) тип контекста, где важно и лексическое значение, и грамматическое оформление.

Многозначность глаголов означает наличие у глагола более чем одного языкового сигнифрикативного значения. С этой точки зрения выбор значения при функционировании глагола в речи можно рассматривать как наложение рефреренциальных ограничений на вероятностную языковую многозначность слова. Контекст содержит указание на сферу, характер, качества явлений действительности, которое делает приемлемым, совместимым с этими данными только одну интерпретацию.

Перевод во многом зависит от контекста, то есть для него, как правило, самым значимым уровнем является уровень предложения.

\section{Русский оригинал}

Президент России Дмитрий Медведев вылетел из Москвы в Краков, чтобы присутствовать на похоронах президента Польши Леха Качиньского. Об этом сообщает «Интерфакс» со ссылкой на пресс-секретаря президента Наталью Тимакову.

Глагол сообщать имеет следующие значения в связи с переводом с русского языка на венгерский: 1. közöl, tudat vkivel vmit 2. átad, kölcsönöz [28]. значения которые и являются в его толковании.

1. о чем. Рассказать кому-н. о чем-н., уведомить кого-н.

2. что кому-чему. Довести до чьего-н. сведения, передать словами.

3. что кому-чему. Передать другому (какое-н. свое качество, свойство; книжн.

4. что чему. Придать (какое-н. свойство, качество), сделать (что-н.) чьим-н. свойством (книжн.) [21].

В этом случае, имея в виду наш пример и контекст, реализуется первое значение глагола, так как в статье речь идет о передаче информации о путешествии президента Медведева. В венгерском переводе значение глагола
Венгерский перевод

Dmitrij Medvegyev orosz elnök Moszkvából Krakkóba repült, hogy részt vegyen a lengyel elnök - Lech Kaczynski - temetésén. - számol be az Interfaksz hírügynökség hivatkozva Natalja Timakovra, az elnök szóvivőjére.

сообщать передается венгерским глаголом beszámol, который соответсвует русскому глаголу, также реализуется основное, первое значение (tn. ige-vmiről jelentést tesz, számot ad, ill. vmit ismertető, vmiről tájékoztató) [26, p. 121].

Интересно заметить, что в русско-венгерском словаре Хадровича-Галди среди значений не цитируется глагол beszámol, все-таки, имея в виду контекст, этот глагол полностью передает содержание глагола-оригинала. В словарной статье венгерско-русского словаря глагол сообщать также не является потенциальным эквивалентом. В венгерском переводе глагол сообщать можно было бы заместить и глаголами, например tudósít, tájékoztat, közöl. В этом случае имеем дело с явлением синонимичности, однако контекст как бы сам определяет вариант глагола beszámol так как 
в случае газетных текстов выбор определяется и по стилистически, имея в виду специальную лексику языка публицистики.
Глагол сообщать выступает и в случае следующего примера, когда венгерский оригинал переводится на русский язык:

\begin{tabular}{|c|c|}
\hline Венгерский оригинал & Русский перевод \\
\hline $\begin{array}{l}\text { A krakkói reptér szóvivője szerint az orosz delegáció két gépe } \\
\text { megérkezett a lengyelországi nagyvárosba. Annak ellenére } \\
\text { indult el az orosz elnök Lengyelországba, hogy az izlandi } \\
\text { vulkán hamufelhöje miatt gyakorlatilag az egész európai } \\
\text { légiközlekedés megbénult. }\end{array}$ & $\begin{array}{l}\text { Приземлились два самолета русской делегации в } \\
\text { крупной польской город, - сообщает пресс-секре- } \\
\text { тарь Краковского аэропорта. Президент России } \\
\text { отправлялся в Польшу несмотря на то, что из-за } \\
\text { облака исландской вулканической пыли сорвался воз- } \\
\text { душное сообщение Европы. }\end{array}$ \\
\hline
\end{tabular}

В венгерском языке через слово szerint переводится содержание глагола сообщать. Слово szerint как послелог по части речи с помощью местоимением перед ним выражает и передает значение глагола сообщать. В толковании послелога он сам сопровождает- ся и глаголом (nu-1. vminek megfelelöen, vmivel egyezőleg 2. vmit tekintetbe véve ill. vmire nézve 3. vmilyen értesülés alapján) [26, p. 1256 ].

Контекст связывает реализацию слова с одним из семантических вариантов глагола сообщать.

\section{Русский оригинал}

Премьер-министр России Владимир Путин заявил, что кандидатура на президентский пост РФ в 2012 году будет принята совместно им и действующим президентом Дмитрием Медведевым, сообщает 26 ноября Интерфакс.

В приведенном примере в венгерском переводе значение глагола сообщать передается глаголом tájékoztat. В этом случае венгерский глагол выступает в своем втором значении, опираясь на его толковании (ts- ige 1. útbaigazít vkit 2. felvilágosítást ad vkinek) [26, p.1296].

В газетных текстах часто присутствует глагол сообщить, при переводе которого всегда следует уделять особое внимание контексту, в соответствии с ним перевод может сильно варьироваться и приобретать значения, характерные только для данного текста. Нужно и при этом учитывать стилистику и коммуникативное задание текста.

В этом же примере употребляется и глагол заявлять, который считается синонимом гла-

\section{Венгерский перевод}

Az orosz kormányfö - Vlagyimir Putyin - a 2012-es választások kapcsán kijelentette: az elnöki posztra való jelölés kérdését a jelenleg hivatalban lévő elnökkel, Dmitrij Medvegyevvel közösen fogják megvitatni tájékoztat november 26-án az Interfaksz hírügynökség.

гола сообщить, (Словарь русских синонимов и сходных по смыслу выражений Н. Абрамова) однако в венгерском языке переводится глаголом kijelent, у которого имеются значения следующие: (ige- sajtó vál 1. határozottan, nyíltan kimond, állít vmit 2. vall kinyilatkoztat vmit 3. vkinek az elköltözését kijelentő lapon a hatóságnak bejelenti) [26, p. 682].

Ярко видно, что первое значение глалога исключительно употребляется в сфере публицистики. Одновременно следует отметить, что у русского глагола сообщить в венгерском языке, в переводе существует несколько вариантов-эквивалентов (рис 1.).

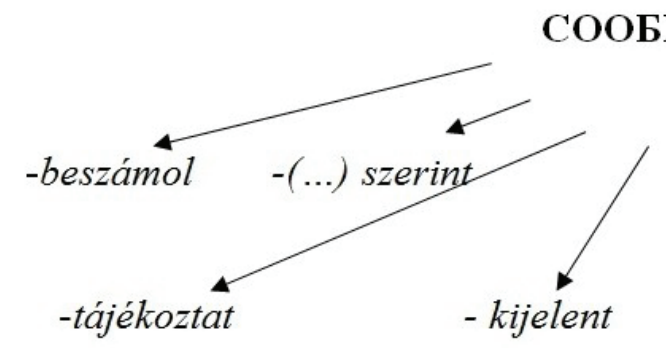

Возможные при переводе венгерские глаголы-эквиваленты (контекстуальные эквивален- 
тить, что у глагола сообщать имеется и идиоматическое, устойчивое значение, которое и проявляется у вышеуказанного венгерского глагола beszámol. (пр: Отец сообщил сыну интерес к наукам. - A fiú örökölte apjától a tudományos érdeklődését. - в венгерском языке глагол beszámol имеет также устойчивое значение - ld. Jól beszámolt neki).

В нижеследующем примере глагол сообщить опять проявляется в русском переводе.

\section{Венгерский оригинал}

Intenzívebbé váltak a spekulációk, hogy a jelenlegi orosz kormányfö ismét elnök akar lenni - közölte kedden az AFP. Vlagyimir Putyin ugyanis azt mondta nagy nyilvánosság elött, hogy Franklin Delano Roosevelt is négyszer volt amerikai elnök.

В случае перевода с венгерского языка на русский глагол közöl переводится как бы автоматически глаголом сообщить, так как русский глагол как и венгерский имеет закрепленную в языке публицистики форму. (közöl: 1. tudtára ad vkinek vmit 2. kinyomtatva közzétesz) [26, p. 765].

Глагол передавать в своем содержании имеет следующие значения:

1) давать кому-либо что-либо.

2) отдавать в собственность другому, поручать другому

\section{Русский перевод}

Стали интенсивнее такие допущения, на основе которых нынешний премьер вновь хочет быть президентом - сообщил АФП во вторник.

Владимир Путин объявил перед всем, что и президент США Франклин Делано Рузвельт избрался четыре раза президентом.

3) делать известным другому, делиться чем-либо.

4) сообщить кому-либо чью-либо просьбу, поручение или то, что услышали, узнали

5) давать возможность услышать, увидеть (с помощью радио, телевидения и т.д.)

Глагол также имеет смысл соответствующий глаголу сообщить, так как в следующем примере переводится на венгерском языке опять глаголом közöl.

\section{Русский оригинал}

Президента США считают самым влиятельным политиком мира 82\% опрошенных, а Владимира Путина, занявшего вторую позицию в списке - 62\%. Российскому президенту Дмитрию Медведеву отдали свои голоса 42\% респондентов, передает ПРАЙМ-ТАСС 23 апреля.

\section{Венгерский перевод}

Az amerikai elnököt a megkérdezettek $82 \%$-a véli a világ legbefolyásosabb politikusának, ezzel szemben Vlagyimir Putyin 62\%-os eredménnyel második helyet foglal a listán. A válaszadók $42 \%$-a szerint Dmitrij Medvegyev orosz elnök a legbefolyásosabb politikus közli a Prime Tass hírügynökség április 23-án.

Глагол передавать имеет несколько эквивалентов в венгерском языке, как и átad, közöl, továbbít, jelent, hírül ad, lead, közvetít, kézbesít. В этом контексте реализуется именно значение közöl, hírül ad. Если проанализируем перевод и при помощи так называемого диагностического предложения, обнаруживается, что контекст как бы разрешает и следующие глаголы, создавая баланс.

Нп.: A válaszadók 42\%-a szerint Dmitrij Medvegyev orosz elnök a legbefolyásosabb politikus - közli/adja hírül/jelenti a Prime Tass hírügynökség április 23-án.

\section{3. Заключение}

Основная идея данной работы заключается в изучении перевода как процесса, того каким образом и при каких условиях реализуются значения глалолов-эквивалентов при переводе с венгерского языка на русский и с русского языка на венгерский. Контекст реализует в языке и однозначности, и многозначности, которое является существенной характеристикой системы языка.
Исходя из этого положения, в качестве объекта анализа мы выбрали несколько, наиболее употребительных в языке газетных текстах глаголов с тем, чтобы провести анализ, как и какое у них значение актуализируется в разных контекстах.

В ходе анализа, мы обратили внимание и на дополнительные значения глаголов, имея в виду идиоматичность и сам контекст. Соотношение многозначности глаголов и контекста можно назвать балансом языка, при котором контекст определяет актуальное значение глагола. Правильного употребления варианта глагольных значений во многом зависит и от жанрово-стилистической характеристики и коммуникативного задания текста. В зависимости от этих факторов варианты перевода могут в значительной мере отличаться, однако сам контекст придает той или иной единице языка однозначность и делает возможным выбор одного из нескольких потенциально существующих эквивалентов данной единицы в переводящем языке. 
Контекст компенсирует языковой многозначности, в большинстве случаев адекватный перевод достигается при помощи использования тематического контекста, а именно референциальных ограничений, которые могут иметь отдельное указание в контексте. Контекст придает той или иной единице языка однозначность и делает возможным выбор одного из нескольких потенциально существующих эквивалентов данной единицы в переводящем языке.

В двух частях статьи мы попытались показать практическую пользу нашего исследова- ния, важность анализа разных значений глаголов, на основе которых можно и раскрыть расхождения между двумя языками.

В результате нашего исследования мы доказали, что изучение многозначности глаголов в свете контекстуального значения важно как для познания самого языка, правильного употребления в общении, так и в создании адекватного перевода. По словам немецкого филолога': „Не бывает переводов с языка на язык а лишь переводы со стиля на стиль,.

\section{Литература}

1. Апресян Ю. Д. Экспериментальное исследование семантики русского глагола. М.: Наука, 1967. 256 с.

2. Балли Ш. Французская стилистика. М.: Эдиториал УРСС, 2001. 392 с.

3. Бархударов Л. С. Язык и перевод (Вопросы общей и частной теории перевода). М. Международные отношения отношения, $1975.240 \mathrm{c}$.

4. Валгина Н. С., Розенталь Д. Э, Фомина М. И. Современный русский язык. М.: Логос, 2002. 528 с.

5. Виноградов В. С. Введение в переводоведение (Общие и лексические вопросы). М.: Издательство института общего среднего образования РАО, 2001. 224 с.

6. Влахов С., Флорин С. Непереводимое в переводе. М.: Международные отношения. 1980. 343 с.

7. Дерибас В. М. Устойчивые глагольно-именные словосочетания русского языка. М.: Русский Язык, 1975. 256 с.

8. Ермолович Д. И. Основа профессионального перевода. М.: РОУ, 1996. 72 с.

9. Жуков Д. Мы - переводчики. М.: Знание, 1975. 112 с.

10. Колшанский Г. В. Контекстная семантика. М.: Наука, 2005. 154 с.

11. Комиссаров В. Н. Современное переводоведение. М.: ЭТС, 2001. 192 с.

12. Крупное В. Н. Лексикографические аспекты перевода. М.: Высшая школа, 1975. 192 с.

13. Милославский И. Г. Краткая практическая грамматика русского языка. М.: Русский язык, 1987. 287 с.

14. Ожегов С. И. Словарь русского языка. М.: Русский язык, 1989. 816 с.

15. Паршин А. Теория и практика перевода. М.: Русский язык, 2000. 202 с.

16. Прагматика слова / отв. ред. В. Д. Девкин. М.: МГПУ им. В.И. Ленина, 1985. 109 с.

17. Рецкер И. Я. Теория перевода и переводческая практика. М.: Международные отношения, 1974. 215 с.

18. Рождественский Ю. В. Общая филология. М.: Новое тысячелетие, 1996. 326 с.

19. Розанова В. В. Краткий толковый словарь русского языка. М.: Русский Язык, 1982. 245 с.

20. Ушакова Д. Н. Толковый словарь. М.: Советская энциклопедия, 1935-1940.

21. Федоров А. В. Основы общей теории перевода. М.: Филология три, 2002. 416 с.

22. Шведова Н. Ю. Типы контекстов, конструирующих многоаспектное описание слов // Русский язык. Текст как целое и компоненты текста. Виноградовские чтения XI. М.: Наука, 1982. С. 142-154.

23. Швейцер А. Д. Теория перевода. Статус, проблемы, аспекты. М.: Наука, 1988. 215 с.

24. Hadrovics László-Gáldi László: Orosz - magyar szótár. Akadémiai Kiadó. Budapest, 1951.

25. Klaudy Kinga: Orosz-magyar fordítástechnika. Tankönyvkiadó Budapest. 1980.

26. Pusztai Ferenc. Magyar Értelmező Kéziszótár. Akadémiai Kiadó. 2003.

27. Tóth László: Igeaspektus és fordítás. In: Translatologia Pannonica. Pécs. 2007. I. évf. 1. szám. C. 136-138.

\section{References}

1. Apresyan Yu. D. Ehksperimental'noe issledovanie semantiki russkogo glagola (Experimental study of the semantics of the Russian verb). Moscow: Nauka, 1967. 256 p. (In Russian).

2. Balli Sh. Francuzskaya stilistika (French stylistics). Moscow: EHditorial URSS, 2001. 392 p. (In Russian).

3. Barhudarov L. S. Yazyk i perevod (Voprosy obshchej i chastnoj teorii perevoda) (Language and Translation (Questions of General and Particular Translation Theory). Moscow: Mezhdunarodnye otnosheniya otnosheniya, 1975. 240 p. (In Russian).

4. Valgina N. S., Rozental' D. Eh, Fomina M. I. Sovremennyj russkij yazyk (Modern Russian language). Moscow: Logos, 2002. 528 p. (In Russian).

5. Vinogradov V. S. Vvedenie v perevodovedenie (Obshchie i leksicheskie voprosy) (Introduction to Translation Studies (General and Lexical Questions). Moscow: Izdatel'stvo instituta obshchego srednego obrazovaniya RAO, 2001. 224 p. (In Russian).

6. Vlahov S., Florin S. Neperevodimoe v perevode (Untranslatable in translation). Moscow: Mezhdunarodnye otnosheniya. 1980. 343 p. (In Russian).

7. Deribas V. M. Ustojchivye glagol'no-imennye slovosochetaniya russkogo yazyka (Stable verbal-nominal word combinations of the Russian language). Moscow: Russkij YAzyk, 1975. 256 p. (In Russian). 
8. Ermolovich D. I. Osnova professional'nogo perevoda (The basis of professional translation). Moscow: ROU, 1996. 72 p. (In Russian).

9. Zhukov D. My - perevodchiki (We are translators). Moscow: Znanie, 1975. 112 p. (In Russian).

10. Kolshanskij G. V. Kontekstnaya semantika (Contextual semantics). Moscow: Nauka, 2005. 154 p. (In Russian).

11. Komissarov V. N. Sovremennoe perevodovedenie (Modern translation studies). Moscow: EHTS, 2001. 192 p. (In Russian).

12. Krupnoe V. N. Leksikograficheskie aspekty perevoda (Lexicographic aspects of translation). Moscow: Vysshaya shkola. 1975. 192 p. (In Russian).

13. Miloslavskij I. G. Kratkaya prakticheskaya grammatika russkogo yazyka (Brief Practical Grammar of the Russian Language). Moscow: Russkij yazyk, 1987. 287 p. (In Russian).

14. Ozhegov S. I. Slovar' russkogo yazyka (Dictionary of Russian). Moscow: Russkij yazyk, 1989. 816 p. (In Russian).

15. Parshin A. Teoriya i praktika perevoda (Theory and practice of translation). Moscow: Russkij yazyk, 2000. 202 p. (In Russian).

16. Pragmatika slova (Pragmatics of the word) / ed by V. D. Devkin. Moscow: MSPU named after V. I. Lenina, 1985. 109 p. (In Russian).

17. Recker I. Ya. Teoriya perevoda i perevodcheskaya praktika (Theory of Translation and Translation Practice). Moscow: Mezhdunarodnye otnosheniya, 1974. 215 p. (In Russian).

18. Rozhdestvenskij Yu. V. Obshchaya filologiya (General Philology). Moscow: Novoe tysyacheletie, 1996. 326 p. (In Russian).

19. Ushakova D. N. Tolkovyj slovar' (Dictionary). Moscow: Sovetskaya ehnciklopediya, 1935-1940. (In Russian).

20. Fedorov A.V. Osnovy obshchej teorii perevoda (Fundamentals of General Theory of Translation). Moscow: Filologiya tri, 2002. 416 p. (In Russian)

21. Shvedova N. Yu. Tipy kontekstov, konstruiruyushchih mnogoaspektnoe opisanie slov (Types of contexts that construct a multidimensional description of words) // Russkij yazyk. Tekst kak celoe i komponenty teksta. Vinogradovskie chteniya XI. Moscow: Nauka, 1982. P. 142-154. (In Russian).

22. Shvejcer A. D. Teoriya perevoda. Status, problemy, aspekty (Translation theory. Status, problems, aspects). Moscow: Nauka, 1988. 215 p. (In Russian).

23. Hadrovics László-Gáldi László: Orosz - magyar szótár. Akadémiai Kiadó. Budapest, 1951.

24. Klaudy Kinga: Orosz-magyar fordítástechnika. Tankönyvkiadó Budapest. 1980.

25. Pusztai Ferenc. Magyar Értelmező Kéziszótár. Akadémiai Kiadó. 2003.

26. Tóth László: Igeaspektus és fordítás. In: Translatologia Pannonica. Pécs. 2007. I. évf. 1. szám. C. 136-138. 